\title{
Epidemiological Evaluation of Head and Neck Sarcomas in Iran (the Study of 105 Cases Over 13 Years)
}

\author{
Batoul Alishahi, ${ }^{1}$ Neda Kargahi, ${ }^{2}$ and Solmaz Homayouni ${ }^{1, *}$ \\ ${ }_{1}^{1}$ Department of Oral and Maxillofacial Pathology, Dental Research Center, School of Dentistry, Isfahan University of Medical Sciences, Isfahan, IR Iran \\ ${ }^{2}$ Department of Oral and Maxillofacial Pathology, Dental Implant Research Center, School of Dentistry, Isfahan University of Medical Sciences, Isfahan, IR Iran \\ ${ }^{*}$ Corresponding author: Solmaz Homayouni, Department of Oral and Maxillofacial Pathology, Dental Research Center, School of Dentistry, Isfahan University of Medical Sciences, \\ Isfahan, IR Iran. Fax: +98-3136687080, E-mail: solmazhomayoni@yahoo.com
}

Received: July 6, 2015; Accepted: July 11, 2015

Background: Head and neck sarcomas are exceedingly rare and they include $4 \%-10 \%$ of all sarcomas and less than $1 \%$ of all neoplasm of head and neck.

Objectives: The aim of this study is to evaluate the epidemiological characteristics of head and neck sarcomas of patients in Isfahan, Iran. Patients and Methods: In this retrospective study, from the 16000 patients whose files were evaluated, the total number of 105 head and neck sarcomas were collected. They were evaluated with due attention to age, gender of the patients and the most common location of the lesion.

Results: From the total number of 105 (0.6\%) patients with sarcomas, 56 were men (53.33\%) and 49 women (46.66\%). The most common head and neck sarcomas among this population were Osteosarcoma (32 cases, 30.47\%), Chondrosarcoma (14 cases, 13.33\%), and Ewing sarcoma (11 cases, 10.47\%).The most common soft tissue sarcoma was Rabdomiosarcoma. Mandible was the most common location for these lesions.

Conclusions: In this study, the hard tissue sarcomas were more prevalent than soft tissue ones. Hence, special attention should be paid to the patients when being diagnosed.

Keywords: Epidemiology; Sarcoma; Head and Neck

\section{Background}

Sarcomas are a wide range of malignant neoplasm derived from mesechymal tissue. Head and neck sarcomas are exceedingly rare and they make about $4 \%$ $10 \%$ of all sarcomas and less than $1 \%$ of all neoplasm of head and neck (1-7). These lesions are often similar to common benign lesions and include many histological types that can be seen in any anatomical condition. In fact, many of these tumors occur in sites that no mature tissue can be seen $(8,9)$. For this reason it is often difficult to diagnose oral sarcomas and they are not usually diagnosed easily. Because of high recurrence rate and poor prognosis of these tumors, it is necessary to conduct an epidemiological study on the prevalence of these lesion, with consideration of age, gender of the patients and location of lesions $(10,11)$. Therefore, it should be noted that clinician and pathologists are expected to have complete knowledge about these tumors for the precise diagnosis.

So far, numerous studies have been carried out in various countries about the prevalence and distribution of sarcomas. 32 patients with oral sarcoma were studied by Yamaguchi et al. (1) in Japan (2004). The patients average age was reported 42 with a male- female ratio of (3-1). In 2007, Chidzonga and Mahomva (12) studied 88 sarcomas of the oral and maxillofacial region in a period of 24 years. Osteosarcoma was reported to be the most common sarcoma that could be seen in the third decade of life mostly in male and in the mandible. Rhabdomyosarcoma was the most common sarcoma of maxilla. Guevara-Canales et al. (13) in Peru studied 155 patients with oral sarcoma. They reported that Osteosarcoma was the most common oral sarcoma. The mean age of patients with this type of sarcoma was 36 , and the prevalence of the disease was higher in females in mandible. Razmpa (8) conducted a study on head and neck sarcomas in Tehran in 1999. Among 40 patients 28 were males (70\%) and 12 were females (30\%). The age range of the patients was $31-40$. The highest occurrences of sarcomas were osteosarcoma and Rhabdomyosarcoma, respectively.

The epidemiological characteristics of disease vary in geographical areas, and numerous studies have demonstrated geographical variation affects the incidence of different types of sarcomas, ages and genders prevalence. Therefore, conducting such studies is undeniable in com-

Copyright (C) 2015, Iranian Journal of Cancer Prevention. This is an open-access article distributed under the terms of the Creative Commons Attribution-NonCommercial 4.0 International License (http://creativecommons.org/licenses/by-nc/4.0/) which permits copy and redistribute the material just in noncommercial usages, provided the original work is properly cited. 
munities. Hence, the aim of this study is to evaluate the prevalence and distribution of epidemiological characteristics of head and neck sarcomas of patients in Isfahan, Iran, during the period of 2001 - 2014 in comparison with previous studies.

\section{Objectives}

Head and neck sarcomas are exceedingly rare and they include $4 \%-10 \%$ of all sarcomas and less than $1 \%$ of all neoplasm of head and neck. Therefore, the aim of this study is to evaluate the epidemiological characteristics of head and neck sarcomas of patients in Isfahan, Iran.

\section{Patients and Methods}

In the present retrospective study, all the medical records of the patients in the archives of Departments of Pathology in the largest academic medical centers of University of Isfahan from January 2001 - July 2014 were reviewed. The files with different types of sarcomas were extracted, then the samples were evaluated according to age, gender and location of the lesions. The data were analyzed by SPSS (version 13), T-test, Chisquare and Fisher test. The P Value $<0.05$ was statically significant.

\section{Results}

Totally, according to reports obtained from patients' files in the archives of Departments of Pathology in Isfahan, the following results have been revealed: From the total number of 16000 files studied from the year 2001 2014 , the number of 105 cases were with head and neck sarcomas. In other words, about $6 \%$ of all samples were head and neck sarcomas. From the total number of diagnosed sarcomas 56 males (53.33\%) and 49 females (46.66\%) suffered from these malignancies. Fisher's test did not indicate statistically significant difference between males and females. The most common head and neck sarcomas in this population were osteosarcoma (32 cases, 30.47\%), Chondrosarcoma (14 cases, 13.33\%), Ewingsarcoma (11 cases, $10.47 \%)$ respectively. The sarcomas with the lowest frequency among head and neck sarcomas in this study were Kaposi sarcoma seen in 2 cases, and Spindle cell sarcomas and liposarcomas each in 3 cases. The most common location for these sarcomas were in mandible, maxilla, ears and neck respectively. The patients with head and neck sarcomas were from 1 - 85 years old with the mean age of 41 . The frequencies of different types of head and neck sarcomas according to the prevalence of each sarcoma, gender, mean age and the most common location are shown in Table 1.

Table 1. Frequencies of Head and Neck Sarcomas

\begin{tabular}{|c|c|c|c|c|c|}
\hline Type of Disease & Total No. (\%) & Man & Woman & Mean Age & Common Location ${ }^{a}$ \\
\hline Osteosarcoma & $32(30.47)$ & 19 & 13 & 34 & 1- mandible; 2 - maxilla \\
\hline Chondrosarcoma & $14(13.33)$ & 7 & 7 & 30 & 1- mandible; 2 - maxilla \\
\hline Ewing' ssarcoma & $11(10.47)$ & 5 & 6 & 14 & 1- mandible; 2 - maxilla \\
\hline Rhabdomyosarcoma & $8(7.61)$ & 3 & 5 & 9 & Ear \\
\hline Neurogenic sarcoma & $8(7.61)$ & 3 & 5 & 48 & Cranial nerves \\
\hline Synovial sarcoma & $6(5.71)$ & 3 & 3 & 29 & Neck \\
\hline Fibro sarcoma & $6(5.71)$ & 3 & 3 & 36 & Mandible \\
\hline Fibro histocytoma & $4(3.80)$ & - & 4 & 40 & Ear \\
\hline Hemangio sarcoma & $4(3.80)$ & 3 & 1 & 72 & Ear \\
\hline Metastatic sarcoma & $4(3.80)$ & 3 & 1 & 35 & 1- lymph node; 2- palate; 3- nasopharynx \\
\hline Liposarcoma & $3(2.85)$ & 2 & 1 & 76 & 1- tyroid; 2- trachea;3- ear \\
\hline Spindl cell sarcoma & $3(2.85)$ & 3 & - & 48 & Maxilla \\
\hline Kaposi sarcoma & $2(1.90)$ & 2 & - & 67 & 1- ear; 2-mandible \\
\hline Total & 105 & 56 & 49 & 41 & \\
\hline
\end{tabular}

${ }^{\mathrm{a}}$ The most prevalent location of sarcomas in order of their frequency. 
Alishahi B et al.

\section{Discussion}

Sarcomas are a group of malignancies that derived from mesenchymal tissue. Head and neck sarcomas are rare. Epidemiological evaluations in different countries are limited and they present different results about prevalence of various sarcomas. In 2007, Lung et al. (14) studied 1072 patients with head and neck malignancy. It was concluded that $93 \%$ of malignancies were carcinomas and $4 \%$ were sarcoma. These sarcomas were $66 \%$ more common in males. In the present study the total number of 105 cases $(0.6 \%)$ with head and neck sarcomas were reported during this period. In other studies the prevalence of head and neck sarcomas included less than $1 \%$ of all neoplasm of the body $(1,2,4,5)$.

According to the results of this study head and neck sarcomas can occur in an age range (from 1 - 85 years old with the mean age of 41 ). The results of these findings are similar to those of several studies $(1,12,15,16)$. But in the studies by Guevara-Canales et al. (13), Eeles et al. (17) and Pandey et al. (18), the mean age of the patients was slightly less than the present results $(13,17,18)$.

In this study, the number of the males with sarcomas were slightly more than females, but this difference between the two genders was not statistically significant. (P $\geq 0.05$ ). In Yamaguchi (1), Razmpa (8), Chidzonga and Mahomva (12) and Chidzonga (15), Lung et al. (14) and Lajer et al.(19) studies the prevalence of head and neck sarcomas in males were higher than it was in females, but in the study that was done by Guevara-Canales et al. (13) and Singh et al. (16) the prevalence of sarcomas were higher in females.

Osteosarcoma was the most common sarcoma in the present study with a mean age of 34 years and was more common in males. It was mainly seen in mandible. The results were similar to the findings from other studies (1, $6,8,12,14,15,20)$ in spite of the Guevara-Canales et al. (13) study that osteosarcoma was found mainly in females. An investigation in Shiraz revealed the location of these lesions was more prevalent in maxilla. The data of this study indicated that Chondrosarcoma was the second most common head and neck sarcoma with equal gender distribution and predilection for mandible. But in the study conducted by Guevara-Canales et al. (13), it was more common in females. In studies that was done by Chidzonga and Mahomva (12) and Chidzonga (15) this lesion was the most common head and neck sarcoma that was ranked in the third place after Osteosarcoma and Rhabdomyosarcoma, respectively.

According to current result, Ewing's Sarcoma was the third most common one. But there were no gender differences in their prevalence and it was in mandible predominantly. The results of the study done by Guevara-Canales et al. (13) showed this sarcoma was more common in males and in maxilla. In most studies, Rhabdomyosarcoma after osteosarcoma was the second most common sarcoma in head and neck, but in this study it is placed after Osteosarcoma, Chondrosarcoma and Ewing's sarco- mas. $(1-4,8,12,13,21,22)$. In other words, the result of this study demonstrated that the hard tissue sarcomas were more prevalent than the soft tissue ones. This can particularly be considered for Rhabdomyosarcoma.

Similarly, Rhabdomyosarcoma occurred in early ages commonly in girls with the mean age of 9 years $(1,8,13)$. Unlikethe results from study by Chidzonga et al. (12) in which the disease was prominent in boys and was mainly seen in maxilla. Other studies by Kraus, Andrassy and Patel on the prevalence of soft tissue sarcomas shed light on the fact that this type of sarcoma can be seen in infants and children (22-24). Liposarcoma and Kaposi sarcoma had the least prevalence among all types of sarcomas. Because of fewer occurrences of these malignancies in head and neck, the findings were not unexpected. Other studies also confirm these results $(1,13,23,24)$. According to searching methods, racial and geographical differences as well as age and gender differences, all may lead to the various distributions of tumors among patients. Due to the patients' incomplete files and lack of attainment for the patients, following up the information of the patients for evaluating the size of tumor, signs and symptoms, prognosis of the disease and surgical procedures was not possible. According to the results of this study head and neck sarcomas are rare and the hard tissue sarcomas are more prevalent than the soft tissue ones. Osteosarcoma is the most common head and neck sarcoma and Rabdomyosarcoma is the most common soft tissue sarcoma. The results of this study confirm other studies done in different countries. Because of the poor prognosis and misdiagnosis of these lesions, these studies could be suggested for better evaluation of the patients.

\section{Acknowledgment}

None Declared.

\section{Authors' Contributions}

None Declared.

\section{Conflict of Interest}

None Declared.

\section{Financial Disclosure}

None Declared.

\section{References}

1. Yamaguchi S, Nagasawa H, Suzuki T, Fujii E, Iwaki H, Takagi M, et al. Sarcomas of the oral and maxillofacial region: a review of 32 cases in 25 years. Clin Oral Investig. 2004;8(2):52-5.

2. Aljabab AS, Nason RW, Kazi R, Pathak KA. Head and neck soft tissue sarcoma. Indian J Surg Oncol. 2011;2(4):286-90.

3. DeVitaJr VT, Hellman S, Rosenberg SA. Cancer: Principles and practice of oncology. 6 ed. Philadelphia: Lippincott Williams and Wilkins; 2001.

4. Gorsky M, Epstein JB. Head and neck and intra-oral soft tissue sarcomas. Oral Oncol. 1998;34(4):292-6.

5. Sturgis EM, Potter BO. Sarcomas of the head and neck region. Curr Opin Oncol. 2003;15(3):239-52. 


\section{Alishahi B et al.}

6. Wanebo HJ, Koness RJ, MacFarlane JK, Eilber FR, Byers RM, Elias EG, et al. Head and neck sarcoma: report of the Head and Neck Sarcoma Registry. Society of Head and Neck Surgeons Committee on Research. Head Neck. 1992;14(1):1-7.

7. Pellitteri PK, Ferlito A, Bradley PJ, Shaha AR, Rinaldo A. Management of sarcomas of the head and neck in adults. Oral Oncol. 2003;39(1):2-12.

8. Razmpa S. Head and neck sarcoma in Tehran. Tehran Univ Dent J 1999;75(3):250-7.

9. Regezi J, Scicibbag. Jordan FI. In: Oral Pathology clinical pathologic correlations. 4 ed. 4, editor. Philadelphia: WB Saunders Co; 2010.

10. Sidappa KT, Krishnamurthy A. Adult soft-tissue sarcomas of the head and neck. Indian JCancer. 2011;48(3):284-8.

11. Hoffman HT, Robinson RA, Spiess JL, Buatti J. Update in management of head and neck sarcoma. Curr Opin Oncol. 2004;16(4):333-41.

12. Chidzonga MM, Mahomva L. Sarcomas of the oral and maxillofacial region: a review of 88 cases in Zimbabwe. BrJ Oral Maxillofac Surg. 2007;45(4):317-8.

13. Guevara-Canales JO, Sacsaquispe-Contreras SJ, Morales-Vadillo R, Sanchez-Lihon J. Epidemiology of the sarcomas of the jaws in a Peruvian population. Med Oral Patol Oral Cir Bucal. 2012;17(2):e201-5.

14. Lung T, Tascau OC, Almasan HA, Muresan O. Head and neck cancer, epidemiology and histological aspects - Part 1: a decade's results 1993-2002. J Craniomaxillofac Surg. 2007;35(2):120-5

15. Chidzonga MM. Oral malignant neoplasia: a survey of 428 cases in two Zimbabwean hospitals. Oral Oncol. 2006;42(2):177-83.

16. Singh RP, Grimer RJ, Bhujel N, Carter SR, Tillman RM, Abudu A Adult head and neck soft tissue sarcomas: treatment and outcome. Sarcoma. 2008;2008:654987.

17. Eeles RA, Fisher C, A'Hern RP, Robinson M, Rhys-Evans P, Henk JM, et al. Head and neck sarcomas: prognostic factors and implications for treatment. Br J Cancer. 1993;68(1):201-7.

18. Pandey M, Thomas G, Mathew A, Abraham EK, Somanathan T, Ramadas K, et al. Sarcoma of the oral and maxillofacial soft tissue in adults. EurJ Surg Oncol. 2000;26(2):145-8.

19. Lajer CB, Daugaard S, Hansen HS, Kirkegaard J, Holmgaard S, Christensen ME. Soft tissue sarcomas of the head and neck: a single-centre experience. Clin Otolaryngol. 2005;30(2):176-82.

20. Fernandes R, Nikitakis NG, Pazoki A, Ord RA. Osteogenic sarcoma of the jaw: a 10-year experience. J Oral Maxillofac Surg. 2007;65(7):1286-91.

21. Weber RS, Benjamin RS, Peters LJ, Ro JY, Achon O, Goepfert H. Soft tissue sarcomas of the head and neck in adolescents and adults. Am J Surg. 1986;152(4):386-92.

22. Kraus DH, Dubner S, Harrison LB, Strong EW, Hajdu SI, Kher U, et al. Prognostic factors for recurrence and survival in head and neck soft tissue sarcomas. Cancer. 1994;74(2):697-702.

23. Andrassy RJ. Advances in the surgical management of sarcomas in children. Am J Surg. 2002;184(6):484-91.

24. Patel SG, Shaha AR, Shah JP. Soft tissue sarcomas of the head and neck: an update. Am J Otolaryngol. 2001;22(1):2-18. 